\title{
Network Analysis of Container Barge Transport in the Port of Antwerp by means of Simulation
}

\author{
An Caris and Gerrit K. Janssens \\ Transportation Research Institute \\ Hasselt University - campus Diepenbeek \\ Wetenschapspark - Building 5 \\ 3590 Diepenbeek, Belgium \\ e-mail: \{an.caris,gerrit.janssens\}@uhasselt.be \\ Cathy Macharis \\ Department MOSI - Transport and Logistics
}

Vrije Universiteit Brussel - Managementschool Solvay

Pleinlaan 2

1050 Brussel, Belgium

e-mail: Cathy.Macharis@vub.ac.be

\begin{abstract}
Inland navigation plays an important role in the hinterland access of the port of Antwerp. In this paper alternative bundling strategies for container barge transport in the port of Antwerp are analyzed. Four alternative hub scenarios are simulated and compared with the current situation with respect to the operational characteristics of the network. Discrete event simulation is used to analyze the impact on waiting times and capacity utilization at potential hubs and at sea terminals. The hub scenarios under investigation are the organization of an intermodal barge hub on the right river bank, an intermodal hub on the left river bank, a first multihub scenario with a local collection/distribution network and a potentially improved multihub scenario taking into account the specific structure of the port of Antwerp. The second multihub scenario offers most opportunities for reducing the turnaround time of all inland terminals. All hub scenarios lead to important efficiency improvements in the handling of barges at sea terminals.
\end{abstract}

\section{Introduction}

In recent years intermodal transport has received an increased attention due to problems of road congestion, environmental concerns and traffic safety. A growing recognition of the strategic importance of speed and agility in the supply chain is forcing firms to reconsider traditional logistic services. As a consequence, research interest in intermodal freight transportation problems is growing. Macharis and Bontekoning (2004) define intermodal transport as the 
combination of at least two modes of transport in a single transport chain, without a change of container for the goods, with most of the route traveled by rail, inland waterway or ocean-going vessel and with the shortest possible initial and final journeys by road. In regions with an extensive waterway network, such as Western Europe, intermodal transport including inland navigation is a good alternative for unimodal road transport. In the intermodal context in Belgium, the importance of inland navigation is increasing. Inland navigation plays an important role in the hinterland access of the port of Antwerp. Hinterland access of ports constitutes a key element in their competitiveness. Ports have become a part of intermodal networks and competition takes place amongst transport chains instead of between ports. However, waiting times of inland barges for container handling in the port of Antwerp have been increasing. Barges have to call at multiple terminals when visiting the port of Antwerp. Calling at several terminals may be a time-consuming process. The queue of barges waiting to be handled may be substantial at peak periods. In light of the expected ongoing increase in container throughput in the port of Antwerp, container barge services need to be reorganized in order to stay competitive as transport mode. Bundling of load offers opportunities to realize a more efficient handling of inland barges in the port area. In this paper alternative bundling strategies for container barge transport in the port of Antwerp are analyzed. The current barge service network is presented in section 2. Research on bundling in intermodal freight transport is discussed in section 3. Section 4 presents the results of analyzing various bundling scenarios by means of simulation. Finally, conclusions and directions for future research are given in section 5 .

\section{Current network configuration}

Two clusters of sea terminals can be identified in the port area of Antwerp. Until recently the main center of activity was situated on the right river bank. With the construction of a new dock (Deurganckdok) in the port of Antwerp, a second cluster of sea terminals emerged on the left river bank. The two clusters are separated by three lock systems. Inland vessels have to pass through a lock in the port area to sail from one cluster to the other. In this paper the clusters are defined as all the sea terminals at one side of the three lock systems. Barges may also sail through the Scheldt-Rhine connection to Rotterdam and Amsterdam.

Shuttle services transport containers from inland terminals to sea terminals in the port area and carry containers from sea terminals to inland destinations in a round trip. Three regions of origin can be identified in the Belgian hinterland network of the port of Antwerp, as depicted in figure 1. The first group of container terminals is situated along the Albert Canal towards the eastern part of Belgium. A second region of origin is located in the central part of the country, connected to the port of Antwerp by the Brussels - Scheldt Sea Canal. The third group of intermodal container flows originates in the basin of the Upper Scheldt and the river Leie. All intermodal container terminals organize shuttle services either to the port of Antwerp or to the ports of Rotterdam and Amsterdam. 


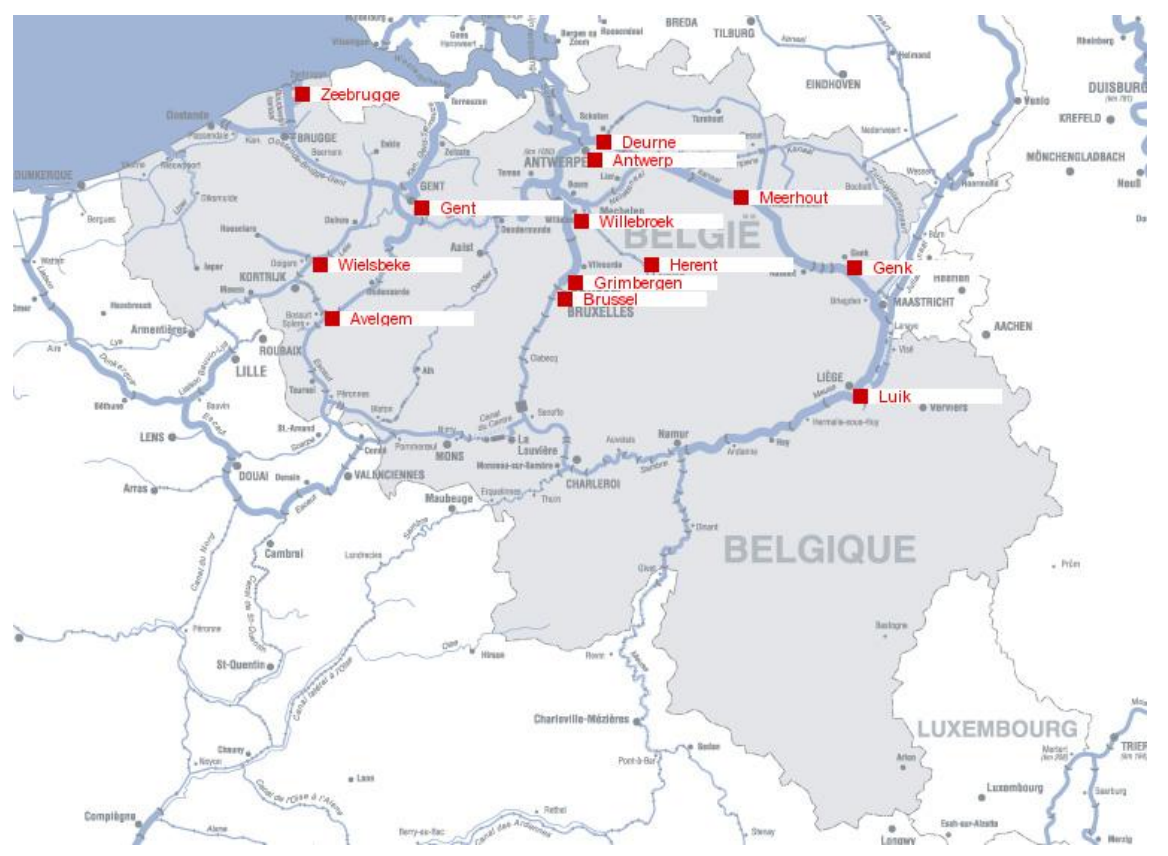

Figure 1: Hinterland network of the port of Antwerp in Belgium

\section{Bundling in barge transport}

According to Crainic and Kim (2007), the relations and trade-offs between volume and frequency of shipping on the one hand, and the cost and delivery time of transportation on the other hand, often dictates the use of consolidation in intermodal transportation services. Consolidation has implications on the strategic and tactical level in freight transport planning. Crainic and Laporte (1997) summarize planning models for freight transportation. Strategic decisions affect the design of the physical infrastructure network. The decision where to locate a consolidation point in the intermodal network is a strategic planning problem in intermodal transport. At the tactical level decisions are made concerning the design of the service network. Service network design involves the selection and scheduling of services to operate, the specification of terminal operations and the routing of freight (Crainic (2000)). A decision needs to be made whether to offer a direct service for a particular origin and destination or to move freight indirectly through a hub terminal and bundle load from nearby origins or to nearby destinations.

A generic framework for transport network design is presented by Woxenius (2007). Kreutzberger (2003) presents major bundling concepts in intermodal freight transport and analyzes their differences in operational costs in intermodal rail operations. Rail-based innovative bundling networks are also evaluated by Janic et al. (1999). When looking at opportunities for consolidation in intermodal barge transport, two options can be discriminated. Bundling may take place in the hinterland network or freight may be bundled in the port area. Groothedde et al. (2005) describes the design and implementation of a collaborative hub network for the distribution of fast moving consumer goods 
using a combination of trucking and inland barges. Bundling in the hinterland network is also aimed by Trip and Bontekoning (2002). The authors explore the possibility of implementing innovative bundling models and new-generation terminals as a means to integrate small flows, mainly from outside economic areas, in the intermodal transport system. Bundling in the hinterland may imply cooperation between terminals or shippers. Ergun et al. (2007) investigate shipper collaboration in the trucking industry. This could be extended to intermodal barge transport. Freight may also be bundled in the port area. Konings (2003) presents a framework to identify possible improvements in the performance of intermodal barge transport by redesigning barge networks. Vessel size and circulation time directly influence the cost and quality performance of barge transport. These factors are determined by the network design, transport market and waterway infrastructure. One potential network concept is the uncoupling of the collection and distribution services in the port area from the trunk haul services to the hinterland, as proposed by Konings (2005). By doing so inland barges do not have to call at multiple sea terminals. They only visit the intermodal barge hub. This leads to a reduction in turnaround time of vessels serving the hinterland. In the collection/distribution network containers with the same origin or destination can be bundled. This enables a more efficient and prompt handling of barges at sea terminals. The author presents and evaluates this consolidation strategy for intermodal transport by barge based on a marginal cost model. In this paper the network concept is elaborated for the port of Antwerp. The construction of a simulation model allows to demonstrate to what extent the waiting times in the port area and the turnaround time of inland barges can be reduced. Various hub scenarios in the port of Antwerp are modeled and analyzed in the next section.

\section{Simulation of hub scenarios}

The objective of our research is to analyze and compare alternative types of bundling networks in the port area of Antwerp. Each scenario has its advantages and disadvantages. A discrete event simulation model is developed in Arena simulation software. The description of the simulation model can be found in Caris et al. (2007). The operations of the inland navigation network are modeled in detail. This enables us to examine ex-ante the effects of alternative ways of organization of container barge transport. Four alternative hub scenarios are simulated and compared with the current situation. Section 4.1 describes the organization of an intermodal barge hub on the right river bank. In section 4.2 an intermodal hub on the left river bank is studied. A first multihub scenario is presented in secion 4.3. A potentially improved multihub scenario for the port of Antwerp is analyzed in section 4.4.

\subsection{Hub on right river bank}

In the first new consolidation strategy an intermodal barge hub is located in the cluster of sea terminals on the right river bank. Shuttle services from inland terminals only visit this intermodal barge hub in the port area to deliver and pickup their load. The intermodal hub organizes shuttle services in the port area to collect containers from and distribute containers to all sea terminals. When 
modeling the new situation, it is assumed that all containers are collected and distributed by barge in the port area. In reality some containers might be transferred by road when the distance between the hub and the sea terminal is small or in urgent cases. A quay length of 500 metres is assumed at the hub. To set a service level for the hub, it is required that all inland containers are delivered within 24 hours to the sea terminals. It is further assumed that on average four shuttle services are organized per day in the collection/distribution network, two in the morning and two in the afternoon, each visiting terminals on the right and/or left river bank. The shuttle services are carried out with vessels of a size of $96 \mathrm{TEU}$ and $196 \mathrm{TEU}$. The organization of the collection/distribution network might be optimized. However, this setting already gives an indication of potential improvements in the relevant performance measures. When comparing the current situation with the new consolidation strategy, no changes are made to the schedules of the inland terminals. It is possible that inland terminals change their departures in the new situation. Other measures to enhance the efficiency can be further simulated. A separate random-number stream is dedicated to each source of randomness in the model in order to synchronize both alternatives as much as possible.

Performance measures relevant for the comparison of the scenarios are discussed next. Ten simulation runs of 672 hours are performed. Table 1 gives the average turnaround times of all inland terminals, expressed in hours. Inland vessels may only sail to Antwerp (Antw) or they can make a combined trip to Antwerp and Rotterdam (Rdam) or Amsterdam (Adam). Standard deviations are mentioned between brackets below the average turnaround times. Table 2 summarizes performance measures in the port area. The average and maximum waiting time before handling, expressed in hours, are given for the sea terminals on the right and left river bank and at the intermodal barge hub. Next, the average and maximum utilization of the quays on the right and left river bank and at the hub are measured. Following Law (2007), paired- $t$ confidence intervals are constructed to compare the results. Table 3 presents the $95 \%$ confidence intervals for which the difference between the current situation and the intermodal barge hub is significant.

The average turnaround times of shuttles between inland terminals along the Albert Canal and the port of Antwerp are all significantly reduced. The maximum turnaround times of these inland terminals also decrease significantly due to the introduction of the hub. Shuttles originating from the Albert Canal can go directly to the intermodal barge hub without having to pass through a lock in the port area. Shuttles from other inland terminals first have to pass through one of the locks to reach the hub. A reduction in turnaround time is also recorded for the terminal in Grimbergen. Table 2 shows that with an equal available quay length, shuttle services in the collection/distribution network of the new consolidation strategy do not have to wait for handling at sea terminals on the right and left river bank. The sea terminals can handle inland containers more efficiently because only shuttle services with consolidated load moor for service. The waiting time at the intermodal hub depends on the available quay length. A quay length of 500 metres is assumed and leads to an average waiting time of 17.82 minutes. Time windows could be negotiated with the inland terminals to reduce the waiting time at the hub at peak hours. Average capacity utilization on the right river bank decreases significantly. Finally, table 2 reveals that at peak moments the maximum capacity utilization decreases with $28.67 \%$ 
Table 1: Average turnaround times current situation and intermodal barge hub right river bank

\begin{tabular}{lcc}
\hline Avg turnaround time & Current & Hub right \\
\hline Deurne - Antw & 15.20 & 9.93 \\
& $(0.47)$ & $(0.35)$ \\
Deurne - Antw/Rdam & 22.08 & 22.98 \\
& $(0.89)$ & $(0.29)$ \\
Meerhout - Antw & 29.24 & 25.59 \\
& $(0.47)$ & $(0.18)$ \\
Meerhout - & 41.70 & 39.68 \\
Antw/Rdam/Adam & $(0.38)$ & $(0.89)$ \\
Genk - Antw & 38.97 & 35.94 \\
& $(0.62)$ & $(0.72)$ \\
Genk - Antw/Rdam & 49.89 & 47.24 \\
& $(0.87)$ & $(0.48)$ \\
Luik - Antw & 46.46 & 42.10 \\
& $(0.34)$ & $(0.12)$ \\
Gent - Antw & 20.62 & 19.43 \\
& $(0.49)$ & $(0.42)$ \\
Wielsbeke - Antw & 38.62 & 39.60 \\
& $(0.42)$ & $(0.41)$ \\
Avelgem - Antw & 41.19 & 40.78 \\
Avelgem - Antw/Rdam & $(0.88)$ & $(2.10)$ \\
& 62.69 & 61.89 \\
Willebroek - Antw & $(0.48)$ & $(0.51)$ \\
& 14.79 & 14.37 \\
Willebroek - Antw/Rdam & $(0.17)$ & $(0.19)$ \\
& 35.59 & 34.91 \\
Grimbergen - Antw & $(0.39)$ & $(0.14)$ \\
& 20.93 & 19.42 \\
Brussel - Antw & $(0.21)$ & $(0.28)$ \\
& 21.91 & 22.42 \\
Brussel - Antw/Rdam & $(0.34)$ & $(0.17)$ \\
Herent - Antw & 40.94 & 40.07 \\
& $(0.29)$ & $(0.42)$ \\
& 21.91 & 21.68 \\
& $(0.19)$ & $(0.40)$ \\
\hline
\end{tabular}

on the left river bank and with $19.67 \%$ on the right river bank. Less quay length is necessary to handle inland containers at peak hours. These figures demonstrate the efficiency improvements at the sea terminals in the port area. The new consolidation strategy has no significant influence on waiting times at locks in the port area. Inland barges constitute only a small part of total lock passages. 
Table 2: Performance measures in the port area: current situation and intermodal barge hub right river bank

\begin{tabular}{lcc}
\hline Port area & Current & Hub Right \\
\hline Avg waiting time & & \\
Right river bank & 0.0629 & 0.0000 \\
& $(0.0306)$ & $(0.0000)$ \\
Left river bank & 0.0557 & 0.0000 \\
& $(0.0115)$ & $(0.0000)$ \\
Hub right & $/$ & 0.2970 \\
& & $(0.0334)$ \\
\hline Max waiting time & & \\
Right river bank & 7.6128 & 0.0000 \\
Left river bank & 4.3095 & 0.0000 \\
Hub right & $/$ & 8.4450 \\
\hline Avg capacity utilization & & \\
Quay right river bank & 0.1666 & 0.1398 \\
& $(0.0017)$ & $(0.0014)$ \\
Quay left river bank & 0.1741 & 0.1808 \\
& $(0.0017)$ & $(0.0016)$ \\
Quay hub right & $/$ & 0.2682 \\
& & $(0.0022)$ \\
\hline Max capacity utilization & & \\
Quay right river bank & 0.9834 & 0.7867 \\
Quay left river bank & 0.9850 & 0.6983 \\
Quay hub right & $/$ & 1.0000 \\
\hline
\end{tabular}

Table 3: Confidence intervals comparing the current situation with a hub on the right river bank

\begin{tabular}{cc}
\hline & $\begin{array}{c}\text { Confidence interval } \\
\text { hub right - current }\end{array}$ \\
\hline Avg turnaround time & \\
Deurne - Antw & $-6.9143 ;-3.6159$ \\
Meerhout - Antw & $-4.7188 ;-2.5713$ \\
Genk - Antw & $-4.8083 ;-1.2481$ \\
Genk - Antw/Rdam & $-5.1158 ;-0.1897$ \\
Luik - Antw & $-5.2091 ;-3.5234$ \\
Grimbergen - Antw & $-2.4003 ;-0.6144$ \\
\hline Avg waiting time & \\
Left river bank & $-0.0818 ;-0.0297$ \\
\hline Avg capacity utilization & \\
Quay right river bank & $-0.0304 ;-0.0233$ \\
\hline
\end{tabular}

\subsection{Hub on left river bank}

In the following scenario the same consolidation strategy is chosen as in the previous scenario, but now the intermodal barge hub is located in the cluster 
of sea terminals on the left river bank. A fixed quay length of 500 metres is provided at the intermodal barge hub. The same service schedule is assumed as in the previous single hub scenario. On average four departures are organized per day in the collection/distribution network. Two shuttle services depart in the morning and two in the afternoon, each handling containers at sea terminals on the right and/or left river bank. The size of barges in the collection/distribution is $96 \mathrm{TEU}$ or $196 \mathrm{TEU}$.

After performing ten simulation runs of 672 hours, the average turnaround times of all inland terminals are reported in Table 4.

Table 4: Average turnaround times current situation and intermodal barge hub left river bank

\begin{tabular}{lcc}
\hline Avg turnaround time & Current & Hub left \\
\hline Deurne - Antw & 15.20 & 14.24 \\
& $(0.47)$ & $(0.53)$ \\
Deurne - Antw/Rdam & 22.08 & 26.63 \\
& $(0.89)$ & $(0.71)$ \\
Meerhout - Antw & 29.24 & 29.67 \\
& $(0.47)$ & $(0.45)$ \\
Meerhout - & 41.70 & 45.57 \\
Antw/Rdam/Adam & $(0.38)$ & $(1.54)$ \\
Genk - Antw & 38.97 & 40.67 \\
& $(0.62)$ & $(0.39)$ \\
Genk - Antw/Rdam & 49.89 & 51.44 \\
& $(0.87)$ & $(0.95)$ \\
Luik - Antw & 46.46 & 46.91 \\
& $(0.34)$ & $(0.23)$ \\
Gent - Antw & 20.62 & 14.80 \\
& $(0.49)$ & $(0.14)$ \\
Wielsbeke - Antw & 38.62 & 28.67 \\
& $(0.42)$ & $(0.24)$ \\
Avelgem - Antw & 41.19 & 35.29 \\
& $(0.88)$ & $(0.46)$ \\
Avelgem - Antw/Rdam & 62.69 & 63.64 \\
Willebroek - Antw & $(0.48)$ & $(0.75)$ \\
& 14.79 & 11.43 \\
Willebroek - Antw/Rdam & $(0.17)$ & $(0.08)$ \\
& 35.59 & 36.14 \\
Grimbergen - Antw & $(0.39)$ & $(0.32)$ \\
& 20.93 & 16.49 \\
Brussel - Antw & $(0.21)$ & $(0.05)$ \\
& 21.91 & 19.15 \\
Brussel - Antw/Rdam & $(0.34)$ & $(0.23)$ \\
Herent - Antw & 40.94 & 41.39 \\
& $(0.29)$ & $(0.27)$ \\
& 21.91 & 18.73 \\
& $(0.19)$ & $(0.10)$ \\
\hline & & \\
& & \\
& &
\end{tabular}


Table 5 compares performance measures in the port area for the current situation and a hub on the left river bank. The average and maximum waiting time before handling and the average and maximum utilization at the sea terminals on the right and left river bank and at the intermodal barge hub are given. The

Table 5: Performance measures in the port area: current situation and intermodal barge hub left river bank

\begin{tabular}{lcc}
\hline Port area & Current & Hub Left \\
\hline Avg waiting time & & \\
Right river bank & 0.0629 & 0.0000 \\
& $(0.0306)$ & $(0.0000)$ \\
Left river bank & 0.0557 & 0.0000 \\
& $(0.0115)$ & $(0.0000)$ \\
Hub left & $/$ & 0.2103 \\
& & $(0.0388)$ \\
\hline Max waiting time & & \\
Right river bank & 7.6128 & 0.0000 \\
Left river bank & 4.3095 & 0.0000 \\
Hub left & $/$ & 8.3733 \\
\hline Avg capacity utilization & & \\
Quay right river bank & 0.1666 & 0.1518 \\
& $(0.0017)$ & $(0.0015)$ \\
Quay left river bank & 0.1741 & 0.1786 \\
& $(0.0017)$ & $(0.0013)$ \\
Quay hub left & $/$ & 0.2689 \\
& & $(0.0027)$ \\
\hline Max capacity utilization & & \\
Quay right river bank & 0.9834 & 0.7867 \\
Quay left river bank & 0.9850 & 0.6983 \\
Quay hub left & $/$ & 0.9900 \\
\hline
\end{tabular}

95\% confidence intervals showing a significant difference between the current situation and the hub scenario on the left river bank are reported in table 6 .

The introduction of an intermodal barge hub on the left river bank has a significantly positive influence on the turnaround times of all inland terminals situated in the central part of the hinterland connected with the Brussels Scheldt Sea Canal and in the basin of the Upper Scheldt and the river Leie. Shuttle services coming from these two regions of origin don't have to pass through locks in the port area to reach the hub on the left river bank. However, a significantly negative influence is observed on the turnaround times of the terminals in Deurne and Genk along the Albert canal. All shuttle services coming from the Albert canal have to pass one of the lock systems in the port area of Antwerp in order to reach the barge hub on the left river bank. This makes the combined trip from Deurne to Antwerp and Rotterdam also less interesting. The barge terminal in Genk already bundles load in the hinterland in the current situation. Consolidating load on the left river bank in the port area is not a good alternative for this inland terminal. Table 5 shows that 
Table 6: Confidence intervals comparing the current situation with a hub on the left river bank

\begin{tabular}{cc}
\hline & $\begin{array}{c}\text { Confidence interval } \\
\text { hub left - current }\end{array}$ \\
\hline Avg turnaround time & \\
Deurne - Antw/Rdam & $2.5314 ; 6.5558$ \\
Genk - Antw & $0.4468 ; 2.9426$ \\
Gent - Antw & $-6.9714 ;-4.6517$ \\
Wielsbeke - Antw & $-11.0999 ;-8.8104$ \\
Avelgem - Antw & $-8.4234 ;-3.3782$ \\
Willebroek - Antw & $-3.7680 ;-2.9509$ \\
Grimbergen - Antw & $-4.9007 ;-3.9916$ \\
Brussel - Antw & $-3.4585 ;-2.0508$ \\
Herent - Antw & $-3.5387 ;-2.8121$ \\
\hline Avg waiting time & \\
Left river bank & $-0.0818 ;-0.0297$ \\
\hline Avg capacity utilization & \\
Quay right river bank & $-0.0188 ;-0.0109$ \\
\hline
\end{tabular}

waiting times at sea terminals on the left and right river bank are eliminated in the collection/distribution network, assuming an equal quay length as in the current situation. A quay length of 500 metres at the hub results in an average waiting time of 12.6 minutes for inland vessels. The maximum waiting time of 8.4 hours can be reduced by introducing agreed time windows for inland barges. The same reduction in maximum capacity utilization is obtained as in the previous hub scenario, described in section 4.1. A capacity gain of $28.67 \%$ is realized on the left river bank and of $19.67 \%$ on the right river bank. Due to the bundling in the port area, sea terminals operate more efficiently. Finally, the consolidation strategy on the left river bank has no significant influence on the waiting times at locks in the port area.

\subsection{Multihub scenario 1}

Both single hub scenarios are mainly advantageous for inland terminals which don't have to pass through a lock system in the port anymore. A multihub scenario with a hub in both clusters of sea terminals on the left and right river bank is investigated next. The first multihub scenario is similar to the multihub service model described in Konings (2005). The collection/distribution of containers in the port area is carried out locally. Inland barges only visit the hubs on the left and right river bank. This scenario offers less economies of scale in the collection/distribution network because redistribution in the port area is organized separately in the two clusters of sea terminals. In order to provide the same level of service at the hubs as in the previous two scenarios, a quay length of 300 metres is assumed at the hub on the left river bank and 400 metres at the hub on the right river bank. Each hub offers two sailings per day, one in the morning and one in the afternoon. Shuttle services in the collection/distribution network are carried out with barges of 96 TEU and 196 
TEU. Table 7 presents the average turnaround times of all inland terminals in the current situation and the first multihub scenario.

Table 7: Average turnaround times current situation and multihub scenario 1

\begin{tabular}{lcc}
\hline Avg turnaround time & Current & Multihub 1 \\
\hline Deurne - Antw & 15.20 & 14.84 \\
& $(0.47)$ & $(0.32)$ \\
Deurne - Antw/Rdam & 22.08 & 21.59 \\
& $(0.89)$ & $(0.92)$ \\
Meerhout - Antw & 29.24 & 28.80 \\
& $(0.47)$ & $(0.59)$ \\
Meerhout - & 41.70 & 41.03 \\
Antw/Rdam/Adam & $(0.38)$ & $(0.60)$ \\
Genk - Antw & 38.97 & 38.13 \\
Genk - Antw/Rdam & $(0.62)$ & $(0.66)$ \\
& 49.89 & 50.62 \\
Luik - Antw & $(0.87)$ & $(1.35)$ \\
& 46.46 & 46.25 \\
Gent - Antw & $(0.34)$ & $(0.39)$ \\
Wielsbeke - Antw & 20.62 & 20.21 \\
& $(0.49)$ & $(0.62)$ \\
Avelgem - Antw & 38.62 & 38.69 \\
& $(0.42)$ & $(0.27)$ \\
Avelgem - Antw/Rdam & 41.19 & 41.39 \\
& $(0.88)$ & $(1.38)$ \\
Willebroek - Antw & 62.69 & 62.54 \\
& $(0.48)$ & $(0.43)$ \\
Willebroek - Antw/Rdam & 14.79 & 14.35 \\
Grimbergen - Antw & $(0.17)$ & $(0.17)$ \\
& 35.59 & 35.47 \\
Brussel - Antw & $(0.39)$ & $(0.31)$ \\
Brussel - Antw/Rdam & 20.93 & 20.61 \\
Herent - Antw & $(0.21)$ & $(0.24)$ \\
& 21.91 & 21.85 \\
& $(0.34)$ & $(0.25)$ \\
& 40.94 & 40.67 \\
& $(0.29)$ & $(0.41)$ \\
& 21.91 & 21.90 \\
& $(0.19)$ & $(0.25)$ \\
\hline & & \\
& & \\
& &
\end{tabular}

Performance measures in the port area are compared in table 8. Significant differences between the current situation and the first multihub scenario are given in table 9.

Only one inland terminal has a significant reduction in turnaround time in this multihub scenario. Inland shuttles visit the hub on the left river bank as well as the hub on the right river bank and have to pass through a lock system in the port area to reach one of the hubs. So inland barges still incur a waiting 
Table 8: Performance measures in the port area: current situation and multihub scenario 1

\begin{tabular}{lcc}
\hline Port area & Current & Multihub 1 \\
\hline Avg waiting time & & \\
Right river bank & 0.0629 & 0.0000 \\
& $(0.0306)$ & $(0.0000)$ \\
Left river bank & 0.0557 & 0.0000 \\
& $(0.0115)$ & $(0.0000)$ \\
Hub right & $/$ & 0.1764 \\
& & $(0.0286)$ \\
Hub left & $/$ & 0.1847 \\
& & $(0.0498)$ \\
\hline Max waiting time & 7.6128 & 0.0000 \\
Right river bank & 4.3095 & 0.0000 \\
Left river bank & $/$ & 7.4321 \\
Hub right & $/$ & 5.5669 \\
Hub left & & \\
\hline Avg capacity utilization & 0.1666 & 0.1547 \\
Quay right river bank & $(0.0017)$ & $(0.0019)$ \\
Quay left river bank & 0.1741 & 0.1770 \\
& $(0.0017)$ & $(0.0020)$ \\
Quay hub right & $/$ & 0.1830 \\
Quay hub left & $/$ & $(0.0038)$ \\
& & 0.2132 \\
Max capacity utilization & & $(0.0020)$ \\
Quay right river bank & 0.9834 & 0.5797 \\
Quay left river bank & 0.9850 & 0.5985 \\
Quay hub right & $/$ & 0.9875 \\
Quay hub left & $/$ & 0.9833 \\
\hline
\end{tabular}

Table 9: Confidence intervals comparing the current situation with multihub scenario 1

\begin{tabular}{cc}
\hline & $\begin{array}{c}\text { Confidence interval } \\
\text { multihub 1 - current }\end{array}$ \\
\hline $\begin{array}{c}\text { Avg turnaround time } \\
\text { Willebroek - Antw }\end{array}$ & $-0.7930 ;-0.0998$ \\
\hline $\begin{array}{c}\text { Avg waiting time } \\
\text { Left river bank }\end{array}$ & $-0.0818 ;-0.0297$ \\
\hline $\begin{array}{c}\text { Avg capacity utilization } \\
\text { Quay right river bank }\end{array}$ & $-0.0160 ;-0.0080$ \\
\hline
\end{tabular}


time at the locks and have to wait and moor at the right hub as well as at the left hub. Waiting times at both hubs could be reduced by providing more quay length, resulting in a reduction in turnaround times of inland barges. Due to the splitting up in two hubs, the hub operations for servicing inland barges is organized less efficient. In total more quay length is required to reach the same level of service as in a single hub scenario. When comparing the multihub scenario with the current situation no waiting times are measured at the sea terminals anymore. In the first multihub scenario $38 \%$ of the quay capacity comes available at the sea terminals on the left river bank and $40 \%$ on the right river bank. This larger capacity gain is due to the local consolidation in the multihub scenario. Furthermore, the hubs could be organized at large call size terminals, where also small container batches for nearby terminals are handled. By doing so, not all containers require an extra handling in the port area.

\subsection{Multihub scenario 2}

In the second multihub scenario also two hubs are provided, one in the cluster of sea terminals on the right river bank and the other in the cluster of sea terminals on the left river bank. However, inland barges only visit a single hub for which they don't have to pass through a lock system in the port area. As a result inland barges avoid waiting times at locks and only have to queue at a single hub, resulting in a larger reduction of turnaround times. The collection/distribution network is not organized locally. Each hub organizes two shuttle services per day in the collection/distribution network, visiting sea terminals on the right and/or left river bank. A quay length of 500 metres is installed at the right hub and 200 metres at the left hub. Again vessels of size 96 TEU or 196 TEU are applied in the redistribution network.

Average turnaround times of all inland terminals in the current situation and the second multihub scenario are shown in table 10 . Table 11 summarizes performances measures in the port area. Paired- $t$ confidence intervals demonstrating a significant difference between the current situation and the second multihub scenario are given in table 12 .

In this adjusted multihub scenario turnaround times of all inland terminals are significantly reduced. This reduction is explained by the fact that inland vessels only call at one hub and don't pass through any lock system in the port area. Waiting times are on average 8.1 minutes at the right hub and 3.4 minutes at the left hub. Maximum waiting times at the hubs can be reduced by arranging time windows with inland vessels. In the collection/distribution network shuttle services are immediately handled at the sea terminals, assuming an equal available quay length as in the current situation. Capacity gains at sea terminals on the right river bank are less in the second multihub scenario than in the first multihub scenario. In the cluster of sea terminals on the right river bank $11 \%$ of the current quay length for handling inland barges becomes available, on the left river bank this amounts to $38 \%$. Less bundling of containers is realized in the collection/distribution network due to the splitting of the hub into two locations and not organizing the redistribution of containers locally. This multihub scenario also offers the possibility of organizing the hubs at a large call-size terminal and thus avoiding the extra handlings for a large part of all containers. This final hub scenario doesn't influence the waiting times at locks in the port area. 
Table 10: Average turnaround times current situation and multihub scenario 2

\begin{tabular}{lcc}
\hline Avg turnaround time & Current & Multihub 2 \\
\hline Deurne - Antw & 15.20 & 9.16 \\
& $(0.47)$ & $(0.14)$ \\
Deurne - Antw/Rdam & 22.08 & 22.73 \\
& $(0.89)$ & $(0.51)$ \\
Meerhout - Antw & 29.24 & 25.64 \\
& $(0.47)$ & $(0.39)$ \\
Meerhout - & 41.70 & 38.84 \\
Antw/Rdam/Adam & $(0.38)$ & $(0.59)$ \\
Genk - Antw & 38.97 & 35.85 \\
& $(0.62)$ & $(0.67)$ \\
Genk - Antw/Rdam & 49.89 & 47.28 \\
& $(0.87)$ & $(0.29)$ \\
Luik - Antw & 46.46 & 41.90 \\
& $(0.34)$ & $(0.23)$ \\
Gent - Antw & 20.62 & 14.73 \\
& $(0.49)$ & $(0.20)$ \\
Wielsbeke - Antw & 38.62 & 28.77 \\
& $(0.42)$ & $(0.24)$ \\
Avelgem - Antw & 41.19 & 35.30 \\
Avelgem - Antw/Rdam & $(0.88)$ & $(0.51)$ \\
& 62.69 & 62.79 \\
Willebroek - Antw & $(0.48)$ & $(0.31)$ \\
& 14.79 & 11.45 \\
Willebroek - Antw/Rdam & $(0.17)$ & $(0.07)$ \\
& 35.59 & 35.81 \\
Grimbergen - Antw & $(0.39)$ & $(0.25)$ \\
& 20.93 & 16.55 \\
Brussel - Antw & $(0.21)$ & $(0.08)$ \\
Brussel - Antw/Rdam & 21.91 & 19.03 \\
& $(0.34)$ & $(0.17)$ \\
Herent - Antw & 40.94 & 41.30 \\
& $(0.29)$ & $(0.38)$ \\
& 21.91 & 18.75 \\
& $(0.19)$ & $(0.08)$ \\
\hline
\end{tabular}

\section{Conclusions and future research}

Bundling of freight flows is regularly put forward to solve the problem of waiting times in the port area of Antwerp. Four alternative scenarios for constructing a bundling network in the port area are examined with respect to the operational characteristics of the network. Discrete event simulation is used to analyze the impact on waiting times and capacity utilization at potential hubs and at sea terminals. The four alternative scenarios differ in terms of the number of hubs, their location or the organization of the collection/distribution network in the port area. The introduction of an intermodal barge hub in the port area may 
Table 11: Performance measures in the port area: current situation and multihub scenario 2

\begin{tabular}{lcc}
\hline Port area & Current & Multihub 2 \\
\hline Avg waiting time & & \\
Right river bank & 0.0629 & 0.0000 \\
& $(0.0306)$ & $(0.0000)$ \\
Left river bank & 0.0557 & 0.0000 \\
& $(0.0115)$ & $(0.0000)$ \\
Hub right & $/$ & 0.1352 \\
& & $(0.0372)$ \\
Hub left & $/$ & 0.0572 \\
& & $(0.0088)$ \\
\hline Max waiting time & 7.6128 & 0.0000 \\
Right river bank & 4.3095 & 0.0000 \\
Left river bank & $/$ & 8.1493 \\
Hub right & $/$ & 2.7953 \\
Hub left & & \\
\hline Avg capacity utilization & 0.1666 & 0.1583 \\
Quay right river bank & $(0.0017)$ & $(0.0015)$ \\
& 0.1741 & 0.1691 \\
Quay left river bank & $(0.0017)$ & $(0.0018)$ \\
& $/$ & 0.2050 \\
Quay hub right & & $(0.0026)$ \\
Quay hub left & $/$ & 0.1579 \\
& & $(0.0011)$ \\
\hline Max capacity utilization & & \\
Quay right river bank & 0.9834 & 0.8696 \\
Quay left river bank & 0.9850 & 0.5985 \\
Quay hub right & $/$ & 0.9660 \\
Quay hub left & $/$ & 0.9100 \\
\hline
\end{tabular}

lead to two major benefits. The turnaround time of inland shuttle services can be reduced because of a reduced waiting time in the port area. Secondly, sea terminals may operate more efficiently because vessels with consolidated load operate in the collection/distribution network in the port area.

The following conclusions concerning the reduction in turnaround time of inland shuttle services are drawn. In the first two scenarios a single hub is provided in the cluster of sea terminals on the left or right river bank. These scenarios only offer a reduction in turnaround time for those inland shuttle services that don't have to pass through a lock system in the port area. In the first multihub scenario a hub is installed in both clusters of sea terminals. As a result, inland barges have to queue at both hubs and often have to pass through a lock system. This scenario offers few opportunities for reducing turnaround times of inland vessels. The second multihub scenario takes the specific structure of the port area in Antwerp into account. Inland barges only visit a single hub for 
Table 12: Confidence intervals comparing the current situation with multihub scenario 2

\begin{tabular}{cc}
\hline & $\begin{array}{c}\text { Confidence interval } \\
\text { multihub 2 - current }\end{array}$ \\
\hline Avg turnaround time & $-7.1630 ;-4.9129$ \\
Deurne - Antw & $-4.9773 ;-2.2225$ \\
Meerhout - Antw & $-3.7859 ;-1.9275$ \\
Meerhout - Antw/Rdam/Adam & $-4.5038 ;-1.7326$ \\
Genk - Antw & $-4.5122 ;-0.6957$ \\
Genk - Antw/Rdam & $-5.7121 ;-3.4074$ \\
Luik - Antw & $-7.1644 ;-4.6099$ \\
Gent - Antw & $-10.8017 ;-8.9000$ \\
Wielsbeke - Antw & $-8.3063 ;-3.4596$ \\
Avelgem - Antw & $-3.7752 ;-2.9091$ \\
Willebroek - Antw & $-4.8781 ;-3.8866$ \\
Grimbergen - Antw & $-3.8709 ;-1.8893$ \\
Brussel - Antw & $-3.5707 ;-2.7537$ \\
Herent - Antw & \\
\hline Avg waiting time & $-0.0818 ;-0.0297$ \\
Left river bank & \\
\hline Avg capacity utilization & $-0.0125 ;-0.0043$ \\
Quay right river bank &
\end{tabular}

which they don't have to pass through a lock system. The collection/distribution network is organized jointly for the two hubs. By doing so, the turnaround time of all inland shuttle services may be reduced significantly. The second multihub scenario is therefore the most interesting scenario for all inland terminals. No influence is observed on waiting times at locks in the port area in any hub scenario. Inland container vessels only constitute a very small share of total lock passages.

In all four scenarios barges in the collection/distribution network don't have to wait at the sea terminals, assuming an equal available quay length as in the current situation. The reduced capacity utilization at peak hours is also an indicator for potential efficiency improvements at sea terminals. In the first multihub scenario the collection/distribution network in the port area is organised locally. Simulation results show the largest reductions in maximum capacity utilization in this first multihub scenario. Vessels in the collection/distribution network only carry containers for local sea terminals. Simulation of the second multihub scenario leads to the same efficiency improvement in the cluster of sea terminals on the left river bank, but a smaller efficiency improvement on the right river bank. A better coordination between the hubs may lead to a greater reduction of maximum capacity utilization. Both single hub scenarios offer a substantial efficiency improvement at the sea terminals. In all scenarios it is assumed that all containers in the collection/distribution network are transported by barge. In reality some containers may be carried by truck to a nearby sea terminal and time windows may be fixed at sea terminals for vessels in the collection/distribution network. For these reasons, the simulation results 
represent a lower limit for efficiency improvements in the port area.

In the future inland terminals may adjust their schedules to the new hub strategy in the port area. Time windows could also be agreed between the hub terminal and the inland shuttle services. Hub terminals may be organized at large call size sea terminals. By doing so not all containers need to be handled twice. Future research may investigate the bundling of freight flows in the hinterland. The service network in the hinterland can be modeled as a whole to estimate potential benefits of cooperation between inland terminals.

Acknowledgement: We thank the Belgian Science Policy (BELSPO) for their support on our research project DSSITP (Decision Support Systems for Intermodal Transport Policy) in the research programme "Science for a Sustainable Development - call 2", under contract number SD/TM/08A.

\section{References}

Caris, A., G. K. Janssens, and C. Macharis (2007). A simulation approach to the analysis of intermodal freight transport networks. In Proceedings of the 2007 European Simulation and Modelling Conference, St.Julians, Malta, pp. 283-286.

Crainic, T. G. (2000). Service network design in freight transportation. European Journal of Operational Research 122, 272-288.

Crainic, T. G. and K. H. Kim (2007). Intermodal transportation. In C. Barnhart and G. Laporte (Eds.), Transportation, Volume 14 of Handbooks in operations research and management science, Chapter 8, pp. 467-537. North-Holland.

Crainic, T. G. and G. Laporte (1997). Planning models for freight transportation. European Journal of Operational Research 97, 409-438.

Ergun, Ö., G. Kuyzu, and M. Savelsbergh (2007). Shipper collaboration. Computers 83 Operations Research 34, 1551-1560.

Groothedde, B., C. Ruijgrok, and L. Tavasszy (2005). Towards collaborative, intermodal hub networks. a case study in the fast moving consumer goods market. Transportation Research Part E 41, 567-583.

Janic, M., A. Reggiani, and P. Nijkamp (1999). Sustainability of the European freight transport system: evaluation of innovative bundling networks. Transportation Planning and Technology 23, 129-156.

Konings, R. (2003). Network design for intermodal barge transport. Transportation Research Record 1820, 17-25.

Konings, R. (2005). Smart collection and distribution of containers on barge in the port of Rotterdam. Proceedings of the Nectar Conference 2005 Las Palmas, Gran Canaria.

Kreutzberger, E. D. (2003). The impact of innovative technical concepts for load unit exchange on the design of intermodal freight networks. Transportation Research Record 1820, 1-10. 
Law, A. M. (2007). Simulation modeling $\mathscr{E}$ analysis (Fourth ed.). McGraw Hill.

Macharis, C. and Y. M. Bontekoning (2004). Opportunities for OR in intermodal freight transport research: A review. European Journal of Operational Research 153, 400-416.

Trip, J. J. and Y. Bontekoning (2002). Integration of small freight flows in the intermodal transport system. Journal of Transport Geography 10, 221-229.

Woxenius, J. (2007). Generic framework for transport network designs: Applications and treatment in intermodal freight transport literature. Transport Reviews 27(6). 